\title{
Abnormal testes in reindeer, Rangifer tarandus
}

\author{
N. Leader-Williams
}

\author{
British Antarctic Survey, Natural Environment Research Council and Department of Clinical \\ Veterinary Medicine, Madingley Road, Cambridge, CB3 OET, U.K.
}

\begin{abstract}
Summary. In a sample of reindeer from South Georgia, 4 males were abnormal in that 1 had bilateral cryptorchid testes, 2 each had 1 cryptorchid testis and 1 had a vestigial testis. The antlers of the cryptorchid males were small, but the antler cycle itself was hardly affected.
\end{abstract}

\section{Introduction}

Cryptorchid testes have been reported in two species of deer (roebuck, Capreolus capreolus: Eissner \& Reichart, 1970; elk (wapiti), Cervus canadensis: Hudson, 1950). Hypogonadism (white-tailed deer, Odocoileus virginianus: Taylor, Thomas \& Marburger, 1964; Marburger, Robinson \& Thomas, 1967) and the occurrence of one regressed testis (red deer, Cervus elaphus: Lincoln, 1971) have been reported also. With the exception of Lincoln (1971) all authors reported accompanying antler abnormalities, such as their total absence, poor calcification or retention of the velvet.

This paper reports on 4 male reindeer (Rangifer tarandus) with abnormal testes. They formed part of a sample of 111 animals shot for a study of the relationship between the testicular and antler cycles on the subantarctic island of South Georgia (Leader-Williams, 1979). Abnormalities of reindeer or caribou testes do not appear to have been reported previously.

\section{Materials and Methods}

The testes and epididymides of the 4 abnormal reindeer were processed as described for those which had normal testes (Leader-Williams, 1979), excepting that both testes and epididymides were fixed (Bouin's fluid) and examined histologically. If antlers were present, their height was measured from the casting burr to the tip in a straight line, and each antler was weighed after being sawn off just below the casting burr. The lower detection limit of assays for plasma testosterone was $0.1 \mathrm{ng} / \mathrm{ml}$ for animals $<14$ months of age and $0.4 \mathrm{ng} / \mathrm{ml}$ for older animals. Data from normal, contemporary animals are used for comparison.

\section{Results}

Male 1, aged 11 months, had two scrotal testes, one of which was vestigial, having a smooth, thickened albuginea; Male 2, 39 months of age, had two intra-abdominal testes, while Males 3 and 4, aged 16 and 11 months respectively, each had one scrotal and one inguinal testis (Table 1). The non-scrotal testes were dissected out via the abdomen, and could not have been withdrawn from the scrotum at death. The scrotal testes in Males 1, 3 and 4 were hypertrophied, resulting in a total testis and epididymis weight comparable to that of their normal contemporaries; both testes of Male 2 were small, flaccid and mis-shapen. The histology of the 
hypertrophied scrotal testes of Males 1,3 and 4 was comparable to that of normal contemporaries (Pl. 1, Figs 1 and 2); the only consistent difference in all specimens was the smaller proportion of tissue within the seminiferous tubules of the hypertrophied testes, and it is concluded that the hypertrophy was caused by growth of the entire testis rather than an increase in one component. The abdominal testis of Male 2 (PI. 1, Fig. 4) and the inguinal testis of Male 3 (Pl. 1, Fig. 3) had a reduced seminiferous tubule area, with a small or absent tubular lumen and no spermatids or spermatozoa were present. Surprisingly, spermatozoa and polymorphs were present in the inguinal epididymis of Male $4,1 \frac{1}{2}$ months after they were last found in an animal of the same year class. The inguinal and abdominal testes all contained darkly staining, usually amorphous, sometimes concentrically layered, granular accumulations in the tubules; these were more abundant in the abdominal testes (Pl. 1, Figs 3 and 4). The vestigial testis of Male 1 was not preserved. Plasma testosterone concentrations were comparable with those of normal contemporaries except for Male 2, whose small testes corresponded with a low testosterone level, in spite of his relative abundance of interstitial tissue (Pl. 1, Fig. 4).

Male 4 was 1 stage behind and Male 3 was slightly behind their contemporaries in the antler cycle. The antlers of Males 2, 3 and 4 were small in relation to those of contemporaries (values were not available for a normal 11-month-old male, but Male 4 had the second smallest set of antlers of the 135 - to 11-month-old males with cleaning or hard antlers). All the antlers were, however, mainly symmetrical.

\section{Discussion}

It can be concluded that Male 2 was a bilateral cryptorchid with low androgen levels and was infertile while Males 3 and 4 , although unilaterally cryptorchid, would probably have been fertile because of their scrotal testis and normal androgen concentrations.

Hudson (1950) recorded an antlerless, bilaterally cryptorchid elk (wapiti) which had failed to develop pedicles and Eissner \& Reichart (1970) reported cryptorchid roebuck with poorly calcified antlers and retained velvet. White-tailed deer with hypogonadism due to toxicity or a mineral deficiency in central Texas, had asymmetric, poorly calcified antlers with retained velvet, and sometimes had enlarged pedicles (Taylor et al., 1964; Marburger et al., 1967). These antler abnormalities were thought to be due to reduced testicular function and testosterone secretion. However, there are reports of antlerless male deer of other species which had normal testes and were fertile (mule deer, Odocoileus hemionus: Robinette \& Jones, 1959; red deer: Lincoln, Guinness \& Fletcher, 1973).

In the reindeer studied there was only a slight delay in the antler cycle of the unilateral cryptorchids, which were both young when shot, but no evidence of a delay in the older, bilateral

\section{PLATE 1}

Testis sections $(6 \mu \mathrm{m})$ stained in haematoxylin and eosin, all photographed at $\times 40$ magnification; scale bar $=50 \mu \mathrm{m}$.

Fig. 1. Normal testis from a 16-month-old male shot during the rut.

Fig. 2. Hypertrophied testis of Male 3,16 months of age and shot during the rut. Note the similar seminiferous tubule diameter and proportion of Leydig tissue, but reduced proportion of tissue within tubules, in relation to those of a normal contemporary (Fig. 1), and signs of normal spermatogenic activity.

Fig. 3. Inguinal testis of Male 3. Note the small seminiferous tubules, small or absent lumina, the lack of spermatogenesis, and the amorphous, darkly staining, intratubular granules (arrowed).

Fig. 4. Right abdominal testis of Male 2, 39 months of age, shot at the start of the rut. Note the small seminiferous tubules, the relatively abundant interstitial tissue, and the amorphous or concentrically layered intratubular granules. 
PLATE 1
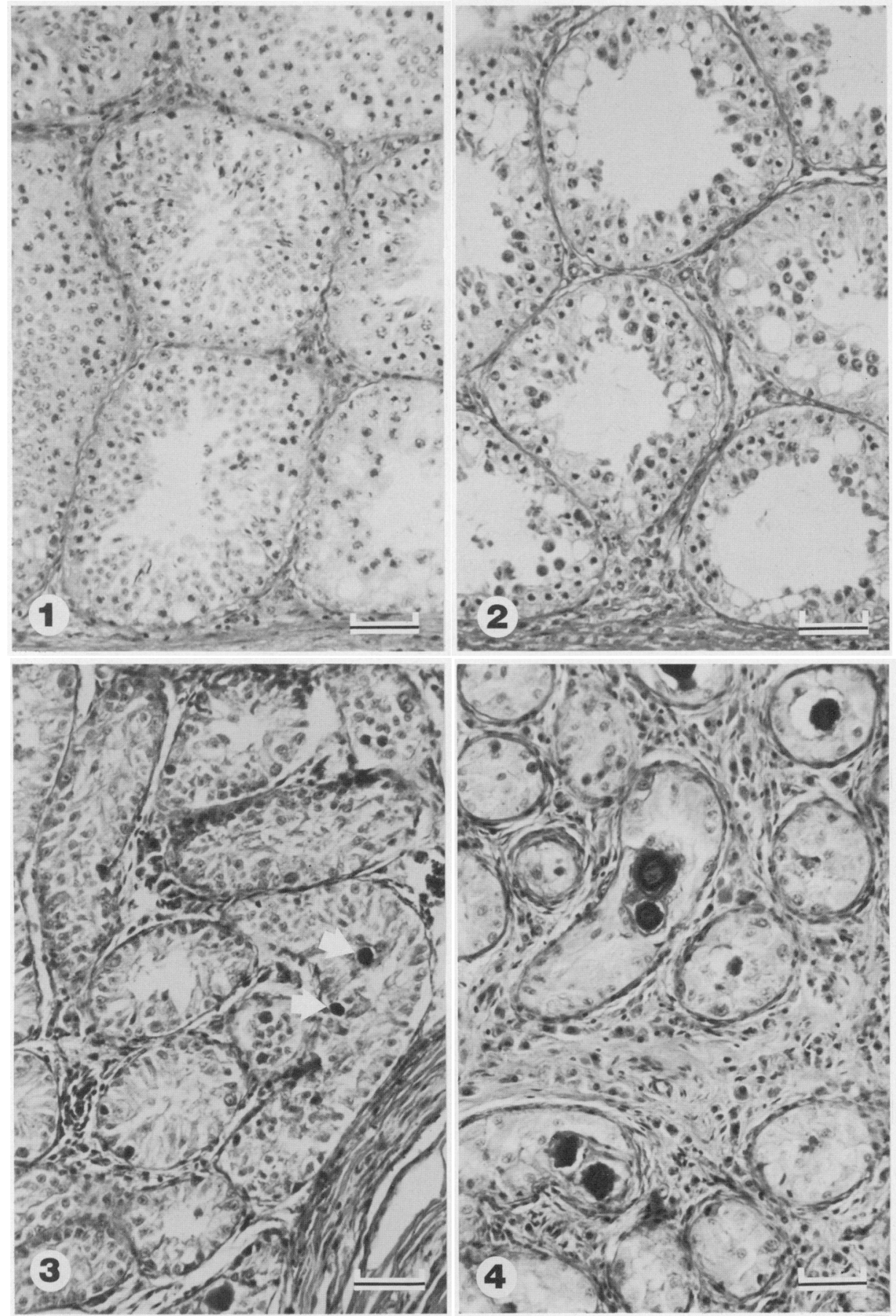

(Facing p. 128) 


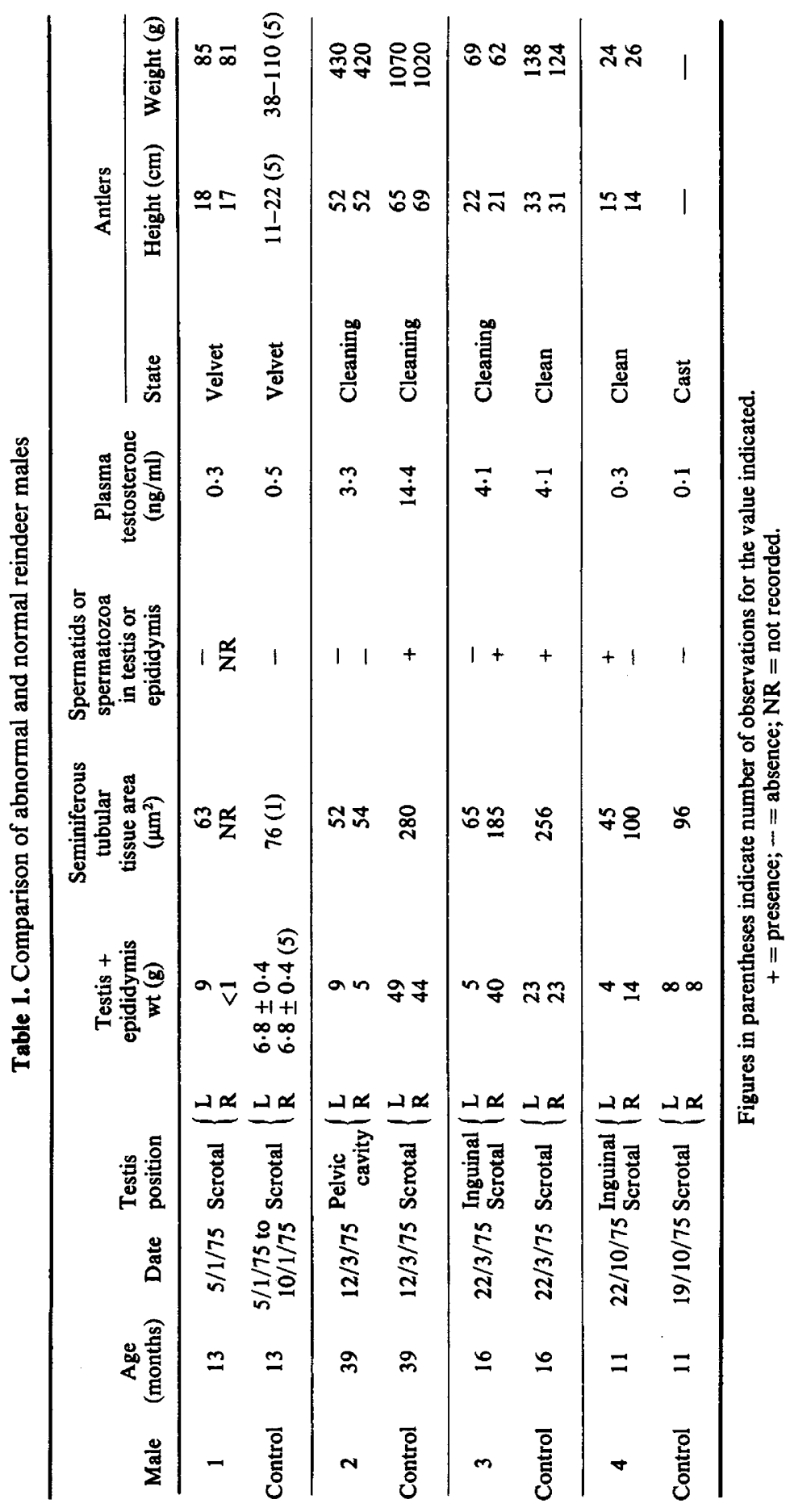


cryptorchid. However, the antlers of all cryptorchids were smaller than those of contemporaries. It can be concluded that the effect of cryptorchidism on the antler cycle of reindeer is minimal in comparison to that in other species, even in the bilaterally affected animal.

\section{References}

Eissner, H. \& Reichart, F. (1970) Perückengeweih und Kryptorchismus beim Rehbock. Z. Jagdwiss. 16, $62-75$.

Hudson, G.E. (1950) Cryptorchid elk (Cervus canadensis) in the Blue Mountains of Washington. $J$. Mammal. 31, 464.

Leader-Williams, N. (1979) Age-related changes in the testicular and antler cycles of reindeer, Rangifer tarandus. J. Reprod. Fert. 57, 117-126.

Lincoln, G.A. (1971) Puberty in a seasonally breeding male, the red deer stag (Cervus elephus L.). $J$. Reprod. Fert. 25, 41-54.
Lincoln, G.A., Guinness, F. \& Fletcher, T.J. (1973) History of a hummel. Part 3. Sons with antlers. Deer 3, 26-31.

Marburger, R.G., Robinson, R.M. \& Thomas, J.W. (1967) Genital hypoplasia of white-tailed deer. $J$. Mammal. 48, 674-676.

Robinette, W.L. \& Jones, D.A. (1959) Antler anomalies of mule deer. J. Mammal. 40, 96-108.

Taylor, D.O.N., Thomas, J.W. \& Marburger, R.G. (1964) Abnormal antler growth associated with hypogonadism in white-tailed deer in Texas. Am.J. vet. Res. 25, 179-185. 